\section{Microscopy}

\section{Coming Events}

2017

Developmental Biology

July 13-17, 2017

Minneapolis, MN

www.sdbonline.org/meeting?ResourcelD=2715

Atomic Layer Deposition

July 15-18, 2017

Denver, CO

www.ald-avs.org

Materials Research Congress

August 20-25, 2017

Cancun, Mexico

www.mrs.org/imrc-2017

International Frontiers of Electron

Microscopy in Materials Science

September 10-15, 2017

Johannesburg, South Africa

http://femms2017.org

Microscience Microscopy Congress and EMAG2017 (mmc2017)

July 3-6, 2017

Manchester, UK

www.mmc-series.org.uk

Denver X-Ray Conference

July 31-August 4, 2017

Big Sky, MT

www.dxcicdd.com

Microscopy \& Microanalysis 2017

August 6-10, 2017

St. Louis, MO

www.microscopy.org

\section{8}

Microscopy \& Microanalysis 2018

August 5-9, 2018

Baltimore, MD

www.microscopy.org

\section{9}

Microscopy \& Microanalysis 2019

August 4-8, 2019

Portland, OR

www.microscopy.org

\section{0}

Microscopy \& Microanalysis 2020

August 2-6, 2020

Milwaukee, WI

www.microscopy.org

\section{1}

Microscopy \& Microanalysis 2021

August 1-5, 2021

Pittsburgh, PA

www.microscopy.org

\section{2}

Microscopy \& Microanalysis 2022

July 31-August 4, 2022

Portland, OR

www.microscopy.org

\title{
Did Life Begin Soon After the Earth Formed?
}

\author{
Stephen W. Carmichael \\ Mayo Clinic, Rochester, MN 55905 \\ carmichael.stephen@mayo.edu
}

There are no confirmed microfossils older than 3,500 million years (Myr) on Earth. Recently Mathew Dodd, Dominic Papineau, Tor Grenne, John Slack, Martin Rittner, Franco Piraino, Jonathan O'Neil, and Crispin Little may have identified evidence of microbial life on Earth from at least 3,770 Myr ago or perhaps as long ago as 4,280 Myr [1]. This would be relatively near the accepted time that the Earth was formed about 4,567 Myr ago!

Microfossils that have biosignatures are considered evidence of early life. These take the form of tubes, knobs, filaments, and/or branching filaments that are likely biogenic. They are similar to younger microfossils in the same kinds of jasper rocks as well as to modern iron-oxidizing bacteria, and they are not the product of any known non-biologic chemical reactions. Dodd et al. pointed out that modern forms of these are known to form at hydrothermal vents on the ocean floor, and therefore life may have begun in a similar environment. A candidate location is a region in northern Québec, Canada, known as the Nuvvuagittuq Supracrustal Belt (NSB) that represents a fragment of the Earth's primitive ocean floor with pillows of lava and where the metamorphosed remains of hydrothermal vents may be preserved as highly localized iron-rich carbonate rocks. Samples from the NSB were examined by light microscopy (transmitted and reflected) as well as scanning electron microscopy (SEM) in back-scattered electron and secondary electron imaging modes. Other microscopy methods were correlated to analyze mineral targets including laser scanning confocal micro-Raman spectroscopy, electron probe micro-analysis, focused ion beam milling, and laser ablation inductively-coupled plasma mass spectrometry.

To assess the biogenicity of the NSB putative microfossils, Dodd et al. considered if the microscopic structures they found could have possibly been formed by abiogenic mechanisms. Considering their structures as twisted iron-containing filaments with microscopic dimensions, identical to younger microfossils and modern bacteria, and their

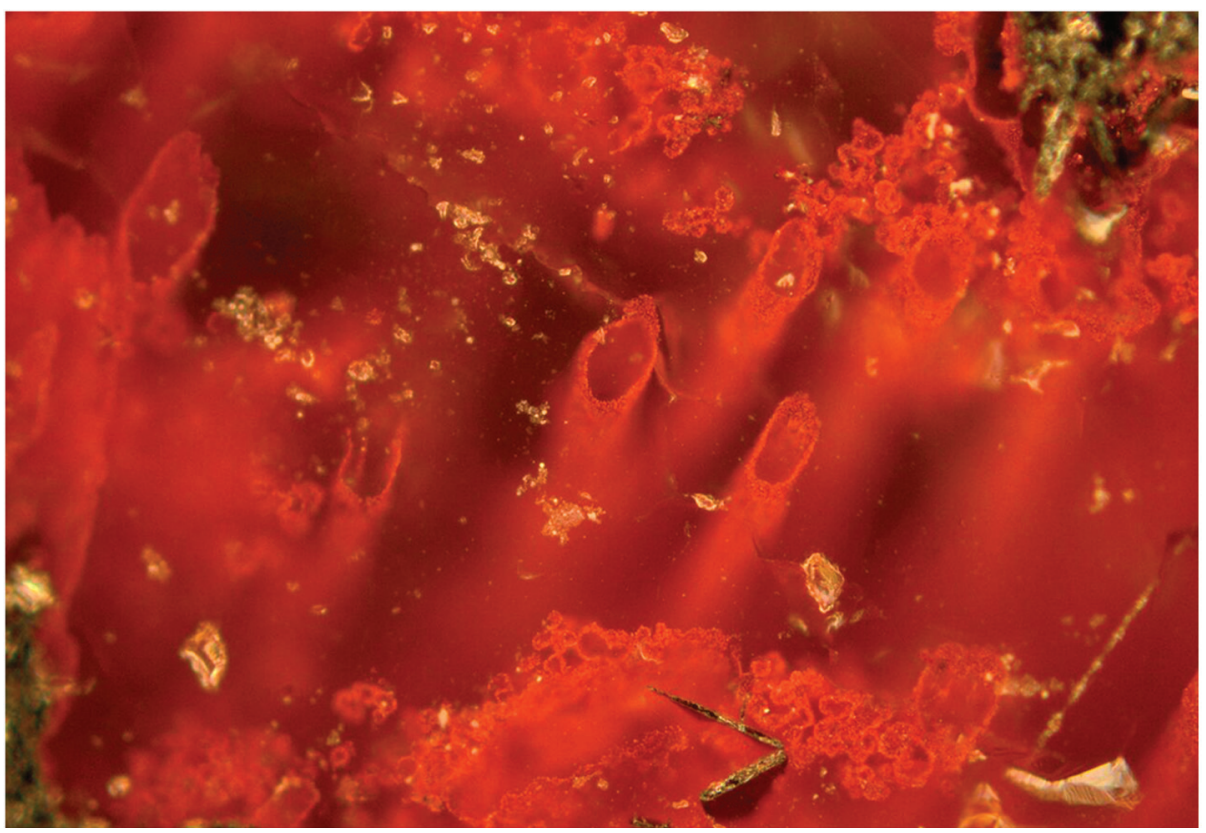

More Meetings and Courses Check the complete calendar near the back of this magazine.

Figure 1: Haematite (containing ferric oxide) tubes from the NSB hydrothermal vent deposits. Photo credit: Matthew Dodd. 


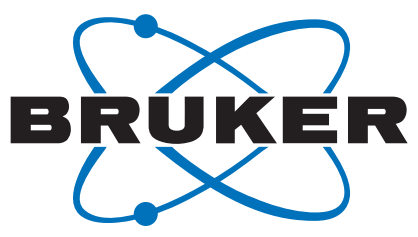

\section{Quantitative Nanomechanical Testing}

\section{Enhanced with the Power of Electron-Microscopy}

Bruker's comprehensive suite of in-situ nanomechanical instruments combines powerful electron microscopy with small-scale mechanical testing. Each system is capable of a wide variety of testing modes, enabling unprecedented insights into nanoscale material behavior across the research spectrum.
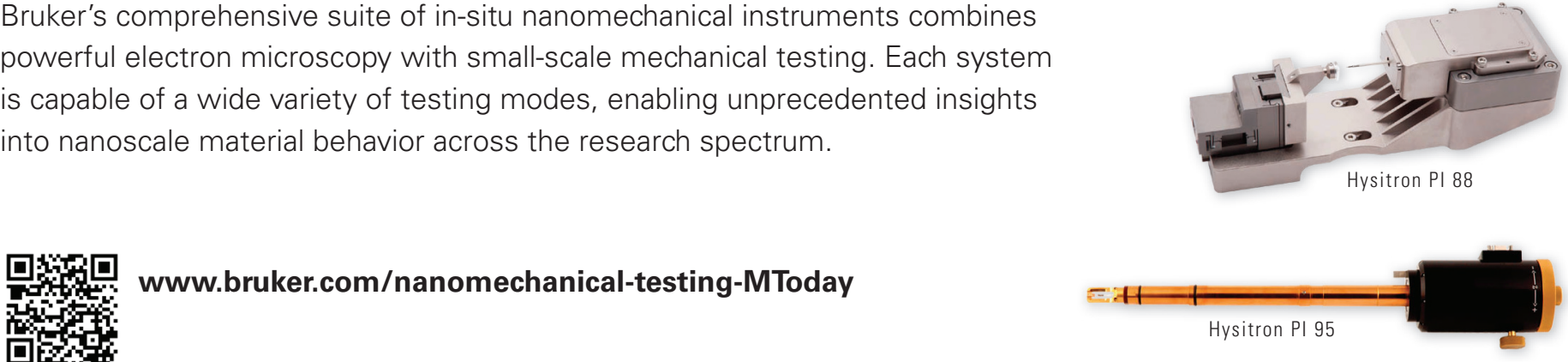

Innovation with Integrity 
attachment to tubes (Figure 1) and terminal knobs, they concluded that their observations could not be explained by any known single or combined abiogenic pathway. Many filaments and tubes were also found inside concretions of jasper, similar to younger fossils of marine animals found in limestone. Of particular note is the presence of carbonate rosettes, 50 to $200 \mu \mathrm{m}$ in diameter, which typically contained microscopic inclusions of carbonaceous material and apatite. Similar modern rosettes with concentrically layered minerals are attributed to mineralized bacteria, although those structures are most likely abiogenic but require biomass to form through chemically oscillating reactions. In fact, rosettes and slightly larger granules from the NSB contain phosphorus (an element vital in biology) in apatite within the carbonate rosettes, which suggests a biologic origin. This conclusion, along with the occurrence of microfossils nearby some structures, indicates an origin involving micro-organisms in the Nuvvuagittuq seafloor more than 3,700 Myr ago.

If these conclusions are supported by future studies from this laboratory and others, then they will have a profound impact on the search for life on other planets. Dodd and his mentor Papineau suggest that ancient submarine-hydrothermal vents should be viewed as increasingly likely sites for origins of life on Earth, as well as primary targets in the search for extraterrestrial life.

\section{References}

[1] MS Dodd et al., Nature 543 (2017) 60-64.

[2] The author gratefully acknowledges Dr. Dominic Papineau for reviewing this article.

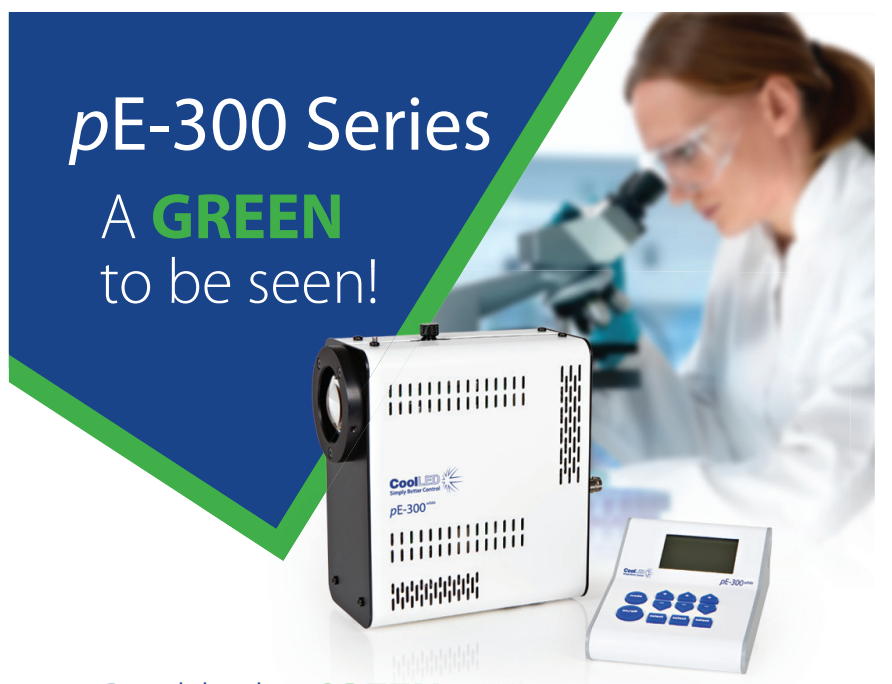

Double the GREEN intensity

View and image samples easier than ever
Simply Better Control

wWw.CoolLED.com

Launching in July at MMC 2017, Manchester UK. Booth \#207

f) 당 in

www.CoolLED.com MT

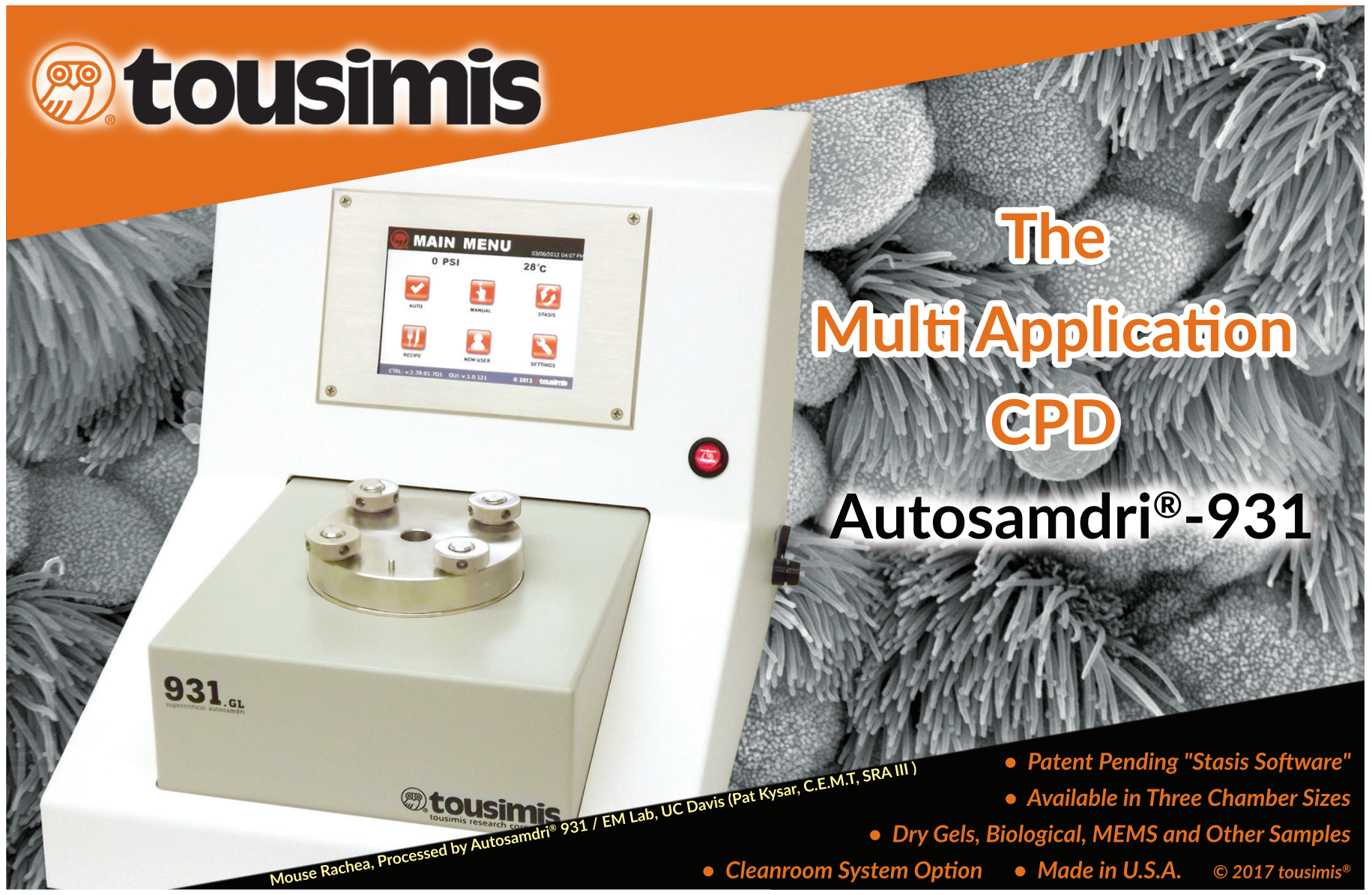


